\title{
Utilization of mango peel in development of instant drink
}

\author{
Anwaar Ahmed ${ }^{*}$, Hafiz Muhammad Rizwan Abid ${ }^{1}$, Asif Ahmad ${ }^{1}$, Naeem Khalid $^{2}$, Sahar Shibli \\ Rai Muhammad Amir ${ }^{1}$, Arshad Mahmood Malik ${ }^{4}$, Muhammad Asghar ${ }^{5}$ \\ ${ }^{1}$ Institute of Food and Nutritional Sciences, PMAS-Arid Agriculture University, Rawalpindi, 46300, Pakistan \\ ${ }^{2}$ Deputy Secretary (Planning), Department of Agriculture, Government of Punjab, Lahore, Pakistan \\ ${ }^{3}$ Food Science Research Institute, National Agricultural Research Centre, Islamabad, 44000, Pakistan \\ ${ }^{4}$ Department of Economics, PMAS-Arid Agriculture University, Rawalpindi, 46300, Pakistan \\ ${ }^{5}$ Post Harvest Research Center, Ayub Agriculture Research Institute, Faisalabad, Pakistan
}



\section{Abstract}

Worldwide, fruit and vegetable processing industries are generating massive agroindustrial by-products. The industrial processing of mango generates a lot of byproducts. Usually the major is with mango peel having a 7-24\% portion of total fruit and not normally utilized. In the present research, mango peel was utilized in the formulation of instant drink as an experiment to harvest its nutrients. The mango peel was dried in the dehydrator and ground to obtain the fine quality powder. The mango peel powder (MPP) obtained was evaluated for its nutritional profile. The powder was added in the instant drink $5 \mathrm{~g}\left(\mathrm{~T}_{1}\right), 10 \mathrm{~g}\left(\mathrm{~T}_{2}\right)$ and $15 \mathrm{~g}\left(\mathrm{~T}_{3}\right)$ concentration per $250 \mathrm{~mL}$ along with water, sugar, citric acid and permitted color and flavor. The instant drink was evaluated at the 0,30 and $60^{\text {th- }}$ day storage intervals for various physicochemical characteristics. Results showed that mango peel is an abundant source of moisture, ash, fat, protein, carbohydrate, and crude fiber. The antioxidant activity, vitamin $\mathrm{C}$ and total phenolic content were $73 \%, 14.8 \mathrm{mg} / 100 \mathrm{~g}$, and $81.3 \mathrm{mg} / \mathrm{g} \mathrm{GAE}$, respectively. The mean values for total sugars, Total Soluble Solids (Brix), Titratable Acidity etc. differed considerably among all the treatments. During the storage interval from 0 to 60 days a significant decrease in $\mathrm{pH}$, total soluble solids and total sugars, free radical scavenging activity and total phenolic content were observed, while the acidity of the drinks was gradually increased. The drink with $5 \mathrm{~g}$ mango peel powder showed the best sensory attributes in terms of flavor, taste and mouthfeel compared to $10 \mathrm{~g}$ and $15 \mathrm{~g}$. This research can be helpful to utilize mango peel waste into food products to harvest the functional, nutraceutical and bioactive compounds.

Keywords: Food waste, Functional food, Storage, Physicochemical properties

\section{How to cite this:}

Ahmed A, Abid HMR, Ahmad A, Khalid N, Shibli S, Amir RM, Malik AM and Asghar M, 2020. Utilization of mango peel in development of instant drink. Asian J. Agric. Biol. 8(3): 260-267. DOI: https://doi.org/10.35495/ajab.2020.02.094 original work is properly cited. 


\section{Introduction}

The fruit and vegetable processing industries are generating a huge quantity of agro-industrial byproducts annually. If not properly treated, these waste products create the problem of disposal and also pose a threat to ecological contamination. Therefore, their competent, inexpensive and exact removal is one of the essential requirements for a friendly environment. These by-products are the intense source of phytochemicals, particularly the fruit peels, and attract the primary consideration of scientists and researchers regarding their extraction and processing. (Manzoor et al., 2012).

Due to enjoyable taste, rich flavor and high nourishing value of Mango (Mangifera indica L., Anacardiaceae) it is named as "king" of fruits. It is a rich source of different micronutrients such as vitamins and minerals, antioxidants and phytochemicals (PalafoxCarlos et al. 2011). Pakistan is ranged at the $5^{\text {th }}$ largest mango producer among the countries of the world and its contribution is about $5.1 \%$ of world production. Pakistan is considered as 4th highest and best quality mango producer in the world (Jegede, 2019).

The mango generally consists of pulp 33-70\%, seed 7$24 \%$ and peel $15-20 \%$ of the total fruit weight. During processing, the main by-products of mango are peels and kernels. Although these products have great importance for use in the manufacture of different products, they are generally disposed-off as waste. Disposal of these by-products imparts significant risk for environmental pollution because they are generally composed of the high content of nitrogen, phosphorus, sugars and high-water activity (Sogi et al., 2013). In addition, the mango processing industries, generally bear significant transport costs to evacuate these wastes from production facilities in order to avoid crosscontamination of the site and the hazardous effects of the waste. This imparts a negative impact on the market future of the mango processing industries. Recent studies have examined that mango peel is a rich source of several vitamins and other photochemical. Captivatingly, the mango peel has greater polyphenol content than present in the pulp (Ajila, 2007).

Powdered mango peel is advantageous because its shelf life is quite long at room temperature, convenient to use and has low transportation costs. It plays important role in the baked products and it can be used in different products such as bread and biscuits, ice cream, extruded foods such as snacks and meat products (Castillo et al., 2013). Instant powdered beverages made from fruit-based products have a good nutritional value because of the high quantity of dietary fiber present in the fruit. The mango peel powder, rich in its nutritional value, is the ideal way for the formulation of instant drinks. (Ajila and Rao, 2013; Benjamin and Spener, 2009).

Observing the significance of mango peel, a study was designed to prepare and characterize the MPP in the development of instant drink. The nutritional characteristics of the mango peel powder and the instant drink were tested with proximate and physiochemical analysis. Instant drink prepared from mango peel powder could be the cheapest source of functional ingredients and bioactive compounds especially antioxidants, polyphenols, flavonoids, anthocyanin and vitamin $\mathrm{C}$.

\section{Material and Methods}

Fresh and healthy local variety (Chaunsa) of Mango fruit was procured from the local market of Rawalpindi. The fruit was immediately transferred for further research to the Institute of Food and Nutritional Sciences, PMAS-Arid Agriculture University Rawalpindi, Pakistan

\section{Development of mango peel powder (MPP)}

The collected mango samples were washed properly with clean water to eliminate the filth and foreign matter. Sterilized knives were used to remove the peel in uniform pieces and blanching of this peel at $98^{\circ} \mathrm{C}$ for $1 \mathrm{~min}$ to inactivate the enzymes. Mango peel powder was obtained by hot air drying in a dehydrator. Mango peel of uniform size pieces was put into the hot air cabinet drier for drying at $50^{\circ} \mathrm{C}$ for approximately 4 hours (until constant weight).

\section{Storage of mango peel powder}

The dried mango peel obtained was subsequently ground to a fine powder and stored at room temperature in a dark place. Mango peel powder was stored in a sealed plastic bag of $75 \mu \mathrm{m}$ thickness at ambient temperature and analyzed for different physicochemical parameters.

\section{Proximate analysis}

The AOAC (2006) method was used to examine the moisture content of MPP by drying at $105^{\circ} \mathrm{C}$ in a forced draft oven (Model: DO-1-30/02, PCSIR, Pakistan) until a constant weight was obtained. The protein content of MPP, as given in AOAC (2006), 
was evaluated. Kjeldahl method (model: D40599, Behr Labor Technik, Gmbh-Germany) was reliable and appropriate in mango peel samples to evaluate crude protein content. The crude fat was analyzed by using the standard method of AOAC (2006) by the Soxtec system. The crude fiber was determined by digesting in $1.25 \%$ sulphuric acid and then in the sodium hydroxide $1.25 \%$ by using equipment Labconco Fibertech (Labconco Corporation Kansas, USA) as mentioned in the AOAC (2006). The muffle furnace (MF1/02, PCSIR, Pakistan) was used for ash by implementing the method of AOAC (2006). The total amount of carbohydrate in peel was also determined by the method given in AOAC (2006).

\section{Ascorbic acid (mg/100g)}

The ascorbic acid in peel powder was evaluated by using spectrophotometer (CE-2021, CECIL Instruments, and England) and the absorbance was recorded at $243 \mathrm{~nm}$ wavelength.

\section{Preparation of antioxidant extracts}

Ethanol was used as a solvent for developing the antioxidant extracts of MPP. For $8 \mathrm{hr}$, extracts were put into the orbital shaker for mixing. Then kept in a centrifuge machine for $15 \mathrm{~min}$ at $7000 \mathrm{rpm}$. For the filtration purposes, vacuum filtration assembly was used for the resulting extracts. Rotary Evaporator was used to recover the remaining solvents at $40^{\circ} \mathrm{C}$ (Rusak et al., 2008). The extracts were used further for the estimation of DPPH (1,1-diphenyl-2-picrylhydrazyl) free radical scavenging and total phenolic content.

\section{Total phenolic contents (mg/g GAE)}

The phenolic compounds of the MPP were estimated by using the Folin-Ciocalteu method (Rekha et al., 2012). A UV-vis spectrophotometer (CECIL CE7200) was used to determine the absorbance at $765 \mathrm{~nm}$. The standard gallic acid calibration/curve was drawn at known concentrations from 0.05 to $0.30 \mathrm{mg} / \mathrm{mL}$.

$\mathrm{C}=\mathrm{c} \times \mathrm{V} / \mathrm{m}$

$\mathrm{C}=$ phenolic compounds in the plant extract in the form of $\mathrm{mg} / \mathrm{g}, \mathrm{GAE}$

$\mathrm{c}=$ calculation from the calibration curve $\mathrm{mg} / \mathrm{ml}$, the concentration of gallic acid

$\mathrm{V}=$ extract volume in $\mathrm{mL}$

$\mathrm{m}=$ Plant extract weight in $\mathrm{g}$

\section{DPPH free radical scavenging activity (\%)}

The scavenging activity of the sample was determined by using the Brand-Williams et al. (1995) test. A new methanol solution of DPPH (1,1-diphenyl-2picrylhdrazyl) for the experiment was developed prior to the test. Many concentrations (40, 80, 120, 160, 200 and $240 \mu \mathrm{g} / \mathrm{mL}$ ) of every sample were mixed to $1 \mathrm{~mL}$ DPPH solution. The resultant solutions were gently shaken and allowed to stand for $30 \mathrm{~min}$ at the ambient temperature. The spectrophotometer was used to record the absorbance at $520 \mathrm{~nm}$, and calculate by using the following formula:

Reduction of absorbance $(\%)=[(\mathrm{AB}-\mathrm{AA}) / \mathrm{AB}] \times 100$

\section{Development of instant drink}

Mango peel powder based instant drink was prepared by adding ingredients (water, sugar, citric acid, CMC, and food-grade flavor) in the MPP. The supplementation of mango peel in the Instant drink was done at 3 different levels of MPP $\left(\mathrm{T}_{1}\right.$ @ 5g/250mL, $\mathrm{T}_{2} @ 10 \mathrm{~g} / 250 \mathrm{~mL}$, and $\mathrm{T}_{3} @ 15 \mathrm{~g} / 250 \mathrm{~mL}$ ). This mango peel-based drink was analyzed for its physiochemical analysis at the storage interval of 0 , 30, 60 days.

\section{Physicochemical evaluation of drink}

Instant drink prepared was evaluated for different parameters that include, total solids, $\mathrm{pH}$ value, titratable acidity, total sugars, ascorbic acid, total phenolic content and antioxidant activity during two months of storage at ambient temperature.

\section{Total soluble solids $\left(\mathrm{Brix}^{\circ}\right)$}

The TSS of the instant drink was analyzed by hand refractometer ((TAMCO, Model No. 90021) using the method as depicted in the AOAC (2006). Homogenous samples were collected on a calibrated refractometer's prism and direct reading (Brix) was taken on scales.

\section{Titratable acidity (\%)}

The titratable acidity of the instant drink was determined by adopting the reference method of the AOAC (2006). The acidity of the instant drink was determined by taking $10 \mathrm{~mL}$ from each sample and diluted with distilled water in a beaker. Phenolphthalein was added (2-3 drops) as an indicator and the samples were titrated against $0.1 \mathrm{~N} \mathrm{NaOH}$ solution up to the light pink color endpoint.

\section{pH value}

The $\mathrm{pH}$ value of instant drink was calculated through a digital $\mathrm{pH}$ meter (InoLab 720, Germany) as 
described in AOAC (2006) by taking 50mL instant drinks in the flask.

\section{Total sugars $(\%)$}

Total sugars of the instant drink were estimated by using the Lane and Eynon method as explained in AOAC (2006).

\section{Sensory evaluation}

A nine-point Hedonic scale, 9 (excellent) to 1 (very poor) as defined by Meilgaard et al. (2007) was used for the sensory evaluation of prepared drinks in terms of color, flavor, taste, mouthfeel and general acceptability. Instant drinks $\left(\mathrm{T}_{1}, \mathrm{~T}_{2}, \mathrm{~T}_{3}\right)$ were evaluated for these characteristics. Written instructions were given to each panelist for the marks of practical drinks. Developed drinks were filled in the polystyrene cups marked with casual codes at room temperature to improve the accuracy.

\section{Statistical analysis}

The data obtained were analyzed by means of statistical tools using a completely randomized design (CRD) using the Minitab 18 statistical program and interpreted by Steel (1997). All measurements were performed threefold and findings are stated as mean \pm standard deviations. For the measurement of the level of consequence, statistical analysis was conducted using variance analysis (ANOVA) et al.

\section{Results and Discussion}

The proximate composition has been presented in Table 1. The moisture content, protein, ash, crude fiber, fat and carbohydrate were, $10.3 \%, 3.8 \%, 3.3 \%$, $8.9 \%, 2.6 \%$ and $86.4 \%$ respectively. The moisture content, fat, protein, fiber, ash and carbohydrate content are important determinants of food. These components determine the nutritive value as well as the shelf value of the product. Characterization of these constituents was essential for the evaluation of components of concern. The results of proximate composition were found in close conformity with the Ajila et al. (2010) who described the values of $10.5 \%$, $3.6 \%, 3.0 \%, 9.4 \%, 2.0 \%$, and $80.7 \%$ for moisture content, protein, ash, crude fiber, fat and carbohydrates respectively.

\section{Bioactive compounds}

The mean values for the antioxidant activity and total phenolic contents were noticed to be $73.1 \%$ and 81.3 $\mathrm{mg} / \mathrm{g}$ GAE respectively (Table 1 ). The presence of these bioactive compounds represents the nutritional qualities and antioxidant potential of the MPP. These antioxidants very essential for the reduction of free radicals from the body and prevent cardiovascular disease. (Bakar et al., 2009). Mango peel contains more anti-oxidant than present in the other fruit peel as the Dragon fruit peel (Hiylocereus polyrhizus) represents $50.1 \%$, banana tissue $52.1 \%$, and quince peel $28 \%$ however it contains less total phenol content than present in the orange peel $(154 \pm 10.2 \mathrm{mg}$ GAE/100g) as reported by Mokbel and Hashinaga (2005). The findings are similar to the results of Imran et al. (2013) who reported the values of $79.4 \mathrm{mg} / \mathrm{g}$ GAE and $71 \%$ for the total phenolic contents and antioxidant activity in their experiment. Similarly, Ajila and Rao (2013) also studied total phenolic contents and antioxidants activity of mango peel powder in the range of $82.7 \mathrm{mg} / \mathrm{g}$ GAE and $79 \%$ respectively.

Table-1: Proximate composition of mango peel

\begin{tabular}{|l|c|}
\hline \multicolumn{1}{|c|}{ Components } & Mean \pm SD \\
\hline Moisture (\%) & $10.3 \pm 0.05$ \\
\hline Protein (\%) & $03.8 \pm 0.15$ \\
\hline Crude Fiber (\%) & $08.9 \pm 0.59$ \\
\hline Ash (\%) & $03.3 \pm 0.17$ \\
\hline Carbohydrate (\%) & $86.4 \pm 0.43$ \\
\hline Fat (\%) & $02.6 \pm 0.11$ \\
\hline Total Phenolic (mg/g GAE) & $81.3 \pm 0.45$ \\
\hline Antioxidant Activity (\%) & $73.0 \pm 0.41$ \\
\hline Ascorbic Acid (mg/100g) & $14.8 \pm 0.26$ \\
\hline
\end{tabular}

\section{Ascorbic acid (mg/100g)}

The ascorbic acid had a mean value of $14.8 \mathrm{mg} / 100 \mathrm{~g}$. Ascorbic acid mainly acts as antioxidants to fight free radicals and play an imperative character in the development and progression of the human body. The presence of this acid along with other bioactive compounds favors the use of this nutrient-rich powder in daily diet. The results are in harmony with Chau and Huang (2003) who reported the mean value of ascorbic acid to be $16.7 \mathrm{mg} / 100 \mathrm{~g}$ in the mango peel.

\section{Physicochemical evaluation of drink}

\section{Titratable acidity (\%)}

Titratable acidity is an important characteristic as acidity gives unique sourness to the product and 
tartness is the key factor in the acceptability of any drink. The effect of treatments and storage on the instant drink is depicted in Table 2. The data represents that the acidity varied significantly among treatments and storage. The mean value for the treatments $T_{1}, T_{2}$, and $T_{3}$ was found to be $0.16,0.17$, and $0.20 \%$ respectively. The predominant acid in the MPP was ellagic acid and by increasing the concentration of the MPP in the treatment, the acidity of the drinks increased. During the storage from 0 to 60 days means values for the treatments increased from 0.16 to 0.19 respectively (Table 3 ). This increase in acidity was endorsed to the breakdown of sugars into carboxyl acids. Ayub et al. (2010) observed a parallel inclination of a decrease in the acidity for the storage of strawberry juice under controlled conditions.

Table-2. Effect of treatments on the chemical characteristics of mango peel drink

\begin{tabular}{|c|c|c|c|}
\hline & $\mathbf{T}_{\mathbf{1}}$ & $\mathbf{T}_{\mathbf{2}}$ & $\mathbf{T}_{\mathbf{3}}$ \\
\hline TA & $0.16 \pm 0.02 \mathrm{~b}$ & $0.17 \pm 0.01 \mathrm{~b}$ & $0.20 \pm 0.02 \mathrm{a}$ \\
\hline pH & $3.72 \pm 0.12 \mathrm{a}$ & $3.62 \pm 0.16 \mathrm{ab}$ & $3.47 \pm 0.14 \mathrm{~b}$ \\
\hline TSS & $3.54 \pm 0.05 \mathrm{c}$ & $4.62 \pm 0.25 \mathrm{~b}$ & $6.9 \pm 0.35 \mathrm{a}$ \\
\hline TS & $10.41 \pm 0.89 \mathrm{c}$ & $12.86 \pm 1.04 \mathrm{~b}$ & $15.59 \mathrm{a}$ \\
\hline DPPH & $47.6 \pm 6.5 \mathrm{c}$ & $50.3 \pm 6.5 \mathrm{~b}$ & $52 \pm 7.54 \mathrm{a}$ \\
\hline TPC & $72.18 \pm 10.6 \mathrm{~b}$ & $73.10 \pm 9.68 \mathrm{ab}$ & $74.50 \pm 13.9 \mathrm{a}$ \\
\hline
\end{tabular}

Means $( \pm \mathrm{SD})$ carrying similar alphabets in a column do not differ significantly $(\mathrm{p}<0.05)$

Table-3. Effect of storage on the chemical characteristics of mango peel drink

\begin{tabular}{|c|c|c|c|c|c|c|}
\hline $\begin{array}{c}\text { Storage } \\
\text { Interval (days) }\end{array}$ & TA & $\mathbf{p H}$ & TSS & TS & DPPH & TPC \\
\hline \multirow{2}{*}{0} & $0.16 \pm$ & $3.74 \pm$ & $4.63 \pm 1$ & $14.37 \pm$ & $56.60 \pm$ & $84.21 \pm$ \\
& $0.02 \mathrm{c}$ & $0.09 \mathrm{a}$ & $.30 \mathrm{~b}$ & $3.52 \mathrm{a}$ & $2.51 \mathrm{a}$ & $4.54 \mathrm{a}$ \\
\hline \multirow{2}{*}{30} & $0.17 \pm$ & $3.60 \pm$ & $5.00 \pm 1$ & $13.36 \pm$ & $50.30 \pm$ & $73.74 \pm$ \\
& $0.02 \mathrm{~b}$ & $0.13 \mathrm{~b}$ & $.17 \mathrm{ab}$ & $2.9 \mathrm{~b}$ & $2.34 \mathrm{~b}$ & $2.35 \mathrm{~b}$ \\
\hline \multirow{2}{*}{60} & $0.19 \pm$ & $3.42 \pm$ & $5.46 \pm 1$ & $11.13 \pm$ & $43.00 \pm$ & $61.84 \pm$ \\
& $0.03 \mathrm{a}$ & $0.14 \mathrm{c}$ & $.01 \mathrm{a}$ & $1.50 \mathrm{c}$ & $1.73 \mathrm{c}$ & $2.11 \mathrm{c}$ \\
\hline
\end{tabular}

Means $( \pm \mathrm{SD})$ carrying similar alphabets in a row do not differ significantly $(\mathrm{p}<0.05)$

\section{pH}

The $\mathrm{pH}$ of any food substance is a very main element in terms of consumer acceptance. The statistical analysis disclosed that there is a momentous fall in ph among treatments. The highest values exist for $T_{1}$ and the lowest value found in $T_{3}$. The main purpose of the decrease in $\mathrm{pH}$ was due to an increase in the acidity among treatments from $T_{1}$ to $T_{3}$. Storage interval also significantly effects the $\mathrm{pH}$. From 0 to 60 days, $\mathrm{pH}$ decreased from 3.74 to 3.42 respectively. This decrease in $\mathrm{pH}$ might be due to the breakdown of sugars and peptic bodies into acidic compounds. The results of the $\mathrm{pH}$ were similar to the findings of with the Kausar et al. (2012) who reported a similar pattern for the $\mathrm{pH}$ decrease during storage in their studies.

\section{Total soluble solids $\left({ }^{\circ} \mathrm{Brix}\right)$}

The results exhibited that there were considerable differences in TSS for treatments and storage interval. Highest mean values recorded in $\mathrm{T}_{3}$ while lowest in the $\mathrm{T}_{1}$. TSS showed an increasing trend from $\mathrm{T}_{1}$ to $\mathrm{T}_{3}$. This increase in the total soluble solid was mainly due to a large amount of total sugar present in the mango peel. However, the mean values during storage interval for TSS also increase from 4.63 to 5.46 from zero to $60^{\text {th }}$ days respectively. This may be due to breakdown of complex sugars e.g. polysaccharides and oligosaccharides into simpler sugars e.g. monosaccharides. Klimczak et al. (2007) record a similar pattern of TSS increase in drinks during storage at the controlled condition in their studies.

\section{Total sugars (\%)}

Total sugars contain all mono and disaccharides present in food substances. The total sugars on instant drinks represent that significant differences exist among treatments. The mean values of $\mathrm{T}_{1}, \mathrm{~T}_{2}, \mathrm{~T}_{3}$, were $11.07,13.98$, and $18.08 \%$ respectively. Total sugars contents increase with the addition of mango peel powder in the drinks. This attributes to the presence of diverse monosaccharides and oligosaccharides in the mango peel powder (Ajila, 2007). Storage of drinks decreased their total sugars contents. Momentous differences exist during the storage period with the highest value recorded (14.37\%) when drinks were freshly prepared compared to the $60^{\text {th }}$ day storage $(11.13 \%)$. The fall in total sugars links to the degradation and conversion of sugars to invert sugars (Zapata et al., 2017). These results are in conformity to the reported by Akhtar et al. (2010). Mokbel and Hashinaga (2005) reported that the total sugar range present in the mango peel was much greater than present in the banana peel.

\section{DPPH (free radical scavenging activity)}

DPPH is the stable free radical model designed to assess antioxidant activity. Antioxidants are important to the human body since they play a crucial role in protecting the body during the metabolism of stress. The statistical data analysis demonstrated significant 
differences (47.6-52) for treatments and storage (56.643). An increasing pattern is seen in $T_{1}$ to $T_{3}$ treatments. The main reason for increasing free radical scavenging activity could be due to an upturn in the content of polyphenols and carotenoids through enhanced MPP fusion. During storage free radical scavenging activity decreases from 0 to days that might be due to oxidation and breakdown of polyphenols due to light and temperature exposure. Ventura et al. (2013) represented a similar trend for pomegranate juice storage in their studies.

\section{Total phenolic content (mg/g GAE)}

Tables 2 \& 3 elucidated that the momentous differences exist in the TPC among treatments (72.18$74.5 \mathrm{mg} / \mathrm{g} \mathrm{GAE}$ ) and during storage interval (84.2 to $61.8 \mathrm{mg} / \mathrm{g}$ GAE). TPC contents increase among treatments with an increase in the incorporation of mango peel powder. Therefore, it was noted that bioactive compounds and the nutraceutical potential of the drinks improve with the rise in the fortification of MPP in the drinks. It was observed that storage adversely affects the TPC and mean values decreases from 84.21 to $61.84 \mathrm{mg} / \mathrm{g}$ GAE. This decrease in TPC links to the deterioration of polyphenol to polyphenol oxidase due to oxidation (Zapata et al., 2017). Similar findings for TPC reduction during storage was given by Varela-Santos et al. (2012) for pomegranate juice in their studies.

\section{Sensory evaluation \\ Color}

The data manifests that color scores were improved with the intensification in the combination of MPP among treatments with the highest value that exists for $\mathrm{T}_{3}$ (8.3) while lowest in $\mathrm{T}_{1}(6.96)$. This variation in color may be due to color pigment's presence in MPP. Two months of storage interval decreases the color scores from 7.1(0days) to 6.4 (60). This variation in color links to the browning reactions between sugars and amino acids (Mishra et al. 2012).

\section{Taste}

The maximum taste score observes in $\mathrm{T}_{1}(8.0)$ while minimum in $\mathrm{T}_{3}$ (6.8). An increase in mango peel powder concentration decreases the taste of drinks due to the increase in the acidity among treatments. Storage intervals showed non-momentous alteration in taste with a maximum score recorded when it was freshly prepared (7.5) and after two months (7.1). The results of color and taste were in close conformity with
Mishra et al. (2012).

\section{Flavor}

Figure $1 \& 2$ represents the flavour scores among treatments. Significant differences exist for flavours with $\mathrm{T}_{1}$ shows the best score among treatments. An increase in organic acid with the addition of MPP concentration in the drinks reduces its flavor. Storage days also show significant variations and the best flavor score was observed when the drinks were freshly prepared. The value changes from 8.1 ( 0 days) to 6.9 (60 days). This change might be due to variations in volatile components with an increase in storage (Ajila, 2007).

\section{Mouthfeel}

The best results for the mouthfeel were recorded in $\mathrm{T}_{1}$ (7.9). Significant differences in mouthfeel represent that the increase in MPP declines its mouthfeel. The storage days reduce the mouthfeel of the drinks with the best results recorded at zero day storage (7.6). The reason for the decline was due to the inversion of sugar content and the formation of carboxylic compounds with storage periods (Kausar et al., 2012). Ahmad et al. (2013) observed a similar result for the storage of drinks in his studies.

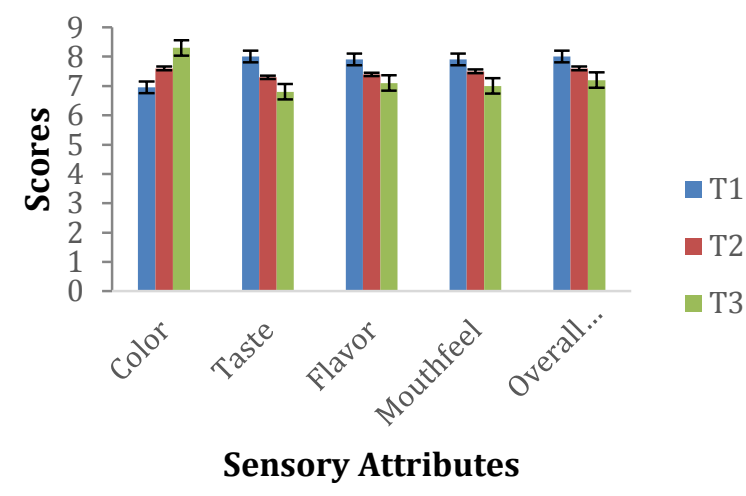

Figure-1: Effect of treatments on sensory scores of mango peel drink

\section{Overall acceptability}

The overall acceptability score of drinks among treatments is demonstrated in Figures $1 \& 2$. The highest score was found in the $\mathrm{T}_{1}(8)$. The acceptability of drinks decreases with an increase in MPP substitution among treatments. Freshly prepared drink shows best results during the storage interval. The overall acceptability score was 8.1 (zero days) when prepared fresh while it changes to 6.4 (60day) during 2 month storage (Figure 2). This change was due to the 
degradation of sugar content and the deterioration of peptic bodies during the storage period (Ajila and Rao, 2013). The findings are similar to the results of Zapata et al. (2017).



Figure-2: Effect of storage on sensory scores of mango peel drink

\section{Conclusion}

Mango peel which is usually discarded as waste possesses good nutraceutical potential and its characterization exhibited a rich source of micronutrients, which can be harvested as a supplement in different food products. The utilization of mango peel at $5 \mathrm{~g} / 250 \mathrm{~mL}$ concentration in instant drinks shows the best result for physio-chemical parameters and shows stability during storage among other treatments. The $5 \mathrm{~g} / 250 \mathrm{~mL}$ concentration of mango peel in the instant drinks also shows the best sensory attributes in terms of flavor, taste and mouthfeel and it can be used in the future on daily basis for the value addition of drinks.

Disclaimer: None.

Conflict of Interest: None.

Source of Funding: The authors are grateful to the Higher Education Commission Islamabad for providing research grant under NRPU funded project No. 20-3157 to carry out this research.

\section{References}

Ahmad RS, Butt MS, Huma N and Sultan MT, 2013. Green tea catechins based functional drink (Green cool) improves the antioxidant status of SD rats fed on high cholesterol and sucrose diets. Pak. J. Pharm. Sci. 26(4): 721-726.

Ajila CM, 2007. Isolation and Characterization of Valuable Components from Mango Peel and
Black Gram Husk. PhD dissertation, University of Mysore, India.

Ajila CM, Aalami M, Leelavathi K and Rao UP, 2010. Mango peel powder: A potential source of antioxidants and dietary fiber in macaroni preparations. Innov. Food Sci. Emerg. Technol. 11(1): 219-224.

Ajila CM and Rao UP, 2013. Mango peel dietary fibre: Composition and associated bound phenolics. J. Funct. Foods. 5(1): 444-450.

Akhtar S, Riaz M, Ahmad A and Nisar A, 2010. Physico-chemical, microbiological and sensory stability of chemically preserved mango pulp. Pak. J. Bot. 42(2): 853-862.

AOAC, 2006. Official Methods of Analysis of Association of Official Analytical Chemists International. In: Horwitz, W. (Ed.), 18th ed. AOAC Press, Arlington, VA, USA

Ayub M, Ullah J, Muhammad A and Zeb A, 2010. Evaluation of strawberry juice preserved with chemical preservatives at refrigeration temperature. Int. J. Nutr. Metab. 2(2): 27-32.

Bakar MFA, Mohamed M, Rahmat A and Fry J, 2009. Phytochemicals and antioxidant activity of different parts of bambangan (Mangifera pajang) and tarap (Artocarpus odoratissimus). Food Chem. 113(2): 479-483.

Benjamin S and Spener F, 2009. Conjugated linoleic acids as functional food: an insight into their health benefits. Nutr. Metab. 6(1): 36. doi:10.1186/1743-7075-6-3.

Brand-Williams W, Cuvelier ME and Berset CLWT, 1995. Use of a free radical method to evaluate antioxidant activity. LWT-Food Sci. Technol. 28(1): 25-30.

Castillo YM, Lares M, Gutiérrez RH, Hernandez MS and Pablo J, 2013. Bioactive compounds of Asai palm fruit and their impact on health. Health. 10: 11. doi:10.3390/foods10x000x.

Chau CF and Huang YL, 2003. Comparison of the chemical composition and physicochemical properties of different fibers prepared from the peel of Citrus sinensis L. Cv. Liucheng. J. Agric. Food Chem. 51(9): 2615-2618.

Imran M, Butt MS, Anjum FM and Sultan JI, 2013. Chemical profiling of different mango peel varieties. Pak. J. Nutr. 12(10): 934-942.

Jegede A, 2019. Top 10 Largest Mango Producing Countries in the World. The Daily Records. 2nd January 2019. 
Kausar H, Saeed S, Ahmad MM and Salam A, 2012. Studies on the development and storage stability of cucumber-melon functional drink. J. Agric. Res. 50(2): 239-248.

Klimczak I, Małecka M, Szlachta $M$ and Gliszczynska-Swigło A, 2007. Effect of storage on the content of polyphenols, vitamin $\mathrm{C}$ and the antioxidant activity of orange juices. J. Food Compos. Anal. 20(3): 313-322.

Manzoor M, Anwar F, Saari N and Ashraf M, 2012. Variations of antioxidant characteristics and mineral contents in pulp and peel of different apple (Malus domestica Borkh.) cultivars from Pakistan. Molecules. 17(1): 390-407.

Meilgaard MC, Civille GV and Carr BT, 2007. Sensory evaluation techniques, 4th ed. C.R.C. Press L.L.C., New York, USA.

Mishra V, Puranik V, Singh V, Verma M, Yadav N and Rai GK, 2012. Development of vitamin C rich value added beverage. Am. J. Food Technol. 7(4): 222-229.

Mokbel MS and Hashinaga F, 2005. Antibacterial and antioxidant activities of banana (Musa, AAA cv. Cavendish) fruits peel. Am. J. Biochem. Biotechnol. 1(3): 125-131.

Palafox-Carlos H, Ayala-Zavala JF and GonzálezAguilar GA, 2011. The role of dietary fiber in the bioaccessibility and bioavailability of fruit and vegetable antioxidants. J. Food Sci. 76(1): R6R15.

Rekha C, Poornima G, Manasa M, Abhipsa V, Devi JP, Kumar HTV and Kekuda TRP, 2012. Ascorbic acid, total phenol content and antioxidant activity of fresh juices of four ripe and unripe citrus fruits. Chem. Sci. Transact. 1(2): 303-310

Rusak G, Komes D, Likic S, Horzic D and Kovac M, 2008. Phenolic content and antioxidative capacity of green and white tea extract depending on extraction conditions and the solvent used. Food Chem. 110(4): 852-858.
Sogi DS, Siddiq M, Greiby I and Dolan KD, 2013. Total phenolics, antioxidant activity, and functional properties of 'Tommy Atkins' mango peel and kernel as affected by drying methods. Food Chem. 141(3): 2649-2655.

Steel RGD, 1997. Analysis of variance II: multiway classifications. Principles and procedures of statistics: A biometrical approach, pp. 204-252.

Ventura J, Alarcón-Aguilar F, Roman-Ramos R, Campos-Sepulveda E, Reyes-Vega ML, BooneVilla VD, Jasso-Villagómez EI and Aguilar CN, 2013. Quality and antioxidant properties of a reduced-sugar pomegranate juice jelly with an aqueous extract of pomegranate peels. Food Chem. 136(1): 109-115.

Varela-Santos E, Ochoa-Martinez A, TabiloMunizaga G, Reyes JE, Pérez-Won M, BrionesLabarca V and Morales-Castro J, 2012. Effect of high hydrostatic pressure (HHP) processing on physicochemical properties, bioactive compounds and shelf-life of pomegranate juice. Innov. Food Sci. Emerg. Technol. 13: 13-22.

Zapata MB, Chaparro DC, Rojano BA, Alzate AF, Restrepo L and Maldonado ME, 2017. Effect of storage time on physicochemical, sensorial, and antioxidant characteristics, and composition of mango (cv. Azúcar) juice. J. Food Sci. 24(5): 143-149

\section{Contribution of Authors}

Ahmed A: Conceived idea, planned research and manuscript write up

Abid HMR: Literature review, lab work and data collection

Ahmad A: Helped in article write up and reviewed manuscript

Khalid N: Conceived idea and designed research methodology

Shibli S: Supervised lab work and data collection Amir RM: Literature review and data interpretation Malik AM: Data analysis and interpretation Asghar M: Manuscript write up and final approval 